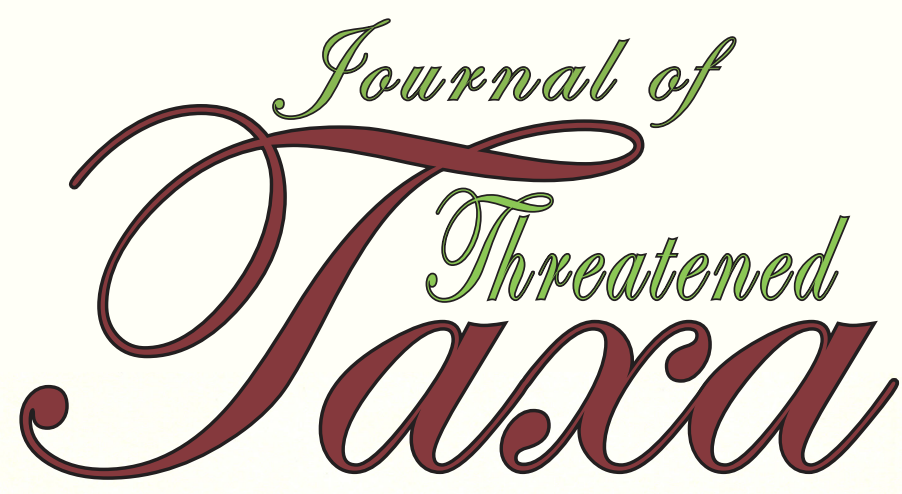

10.11609/jott.2021.13.14.20143-20310 enever.threatenedtaxa.org

26 December 2021 (Online \& Print) Val. 13 | Na. 14 | Pages: 20143-20310 155n 0974-7907 (Online) 155n 0974-7893 (Print)

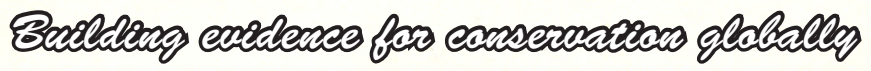

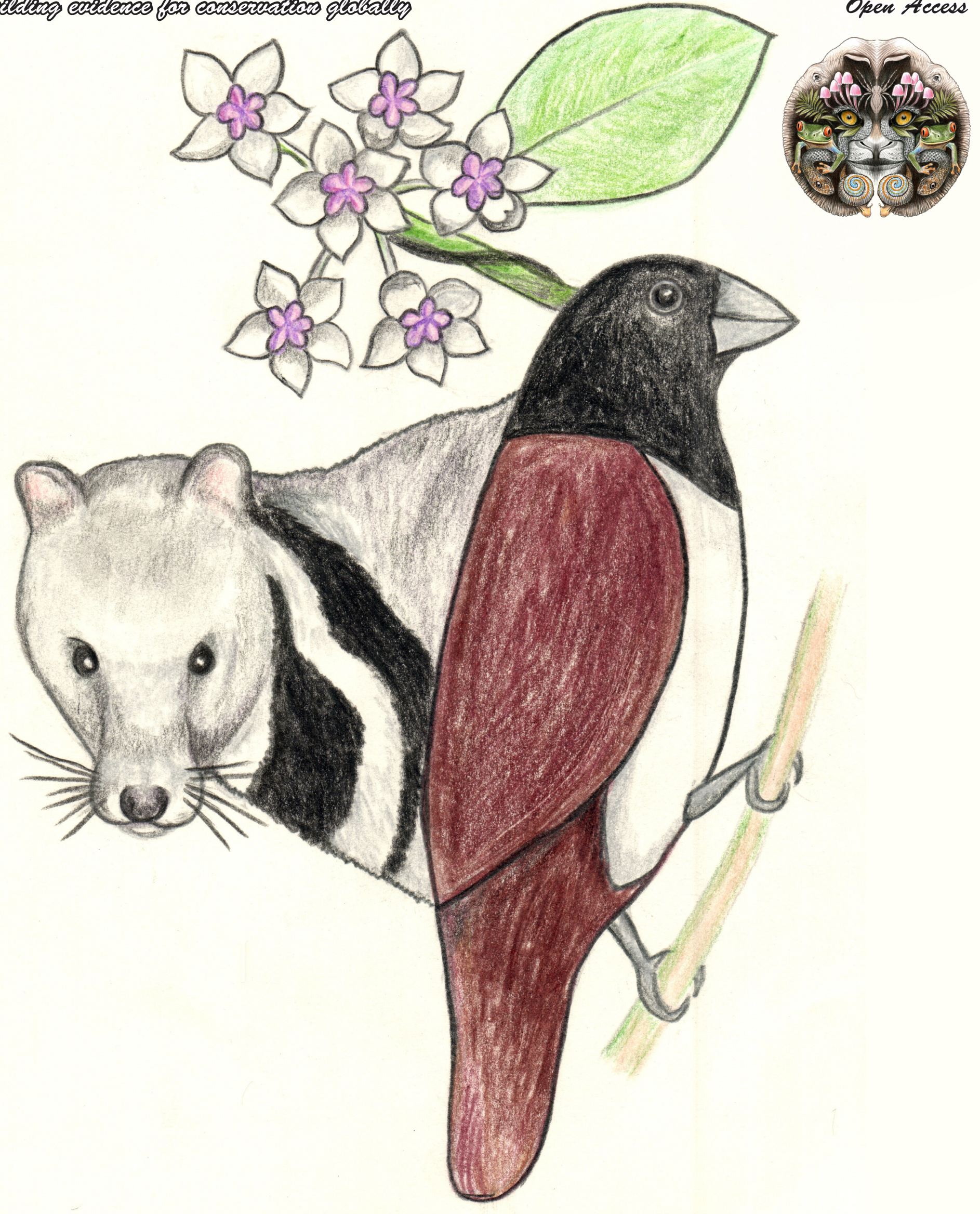

Open Access 


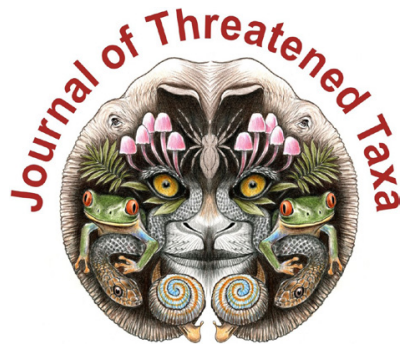

ISSN 0974-7907 (Online); ISSN $0974-7893$ (Print)

Publisher

Host

Wildlife Information Liaison Development Society

www.wild.zooreach.org

Zoo Outreach Organization www.zooreach.org

No. 12, Thiruvannamalai Nagar, Saravanampatti - Kalapatti Road, Saravanampatti, Coimbatore, Tamil Nadu 641035, India

Ph: +91 9385339863 | www.threatenedtaxa.org

Email: sanjay@threatenedtaxa.org

EDITORS

\section{Founder \& Chief Editor}

Dr. Sanjay Molur

Wildlife Information Liaison Development (WILD) Society \& Zoo Outreach Organization (ZOO),

12 Thiruvannamalai Nagar, Saravanampatti, Coimbatore, Tamil Nadu 641035, India

\section{Deputy Chief Editor}

Dr. Neelesh Dahanukar

Noida, Uttar Pradesh, India

\section{Managing Editor}

Mr. B. Ravichandran, WILD/ZOO, Coimbatore, India

\section{Associate Editors}

Dr. Mandar Paingankar, Government Science College Gadchiroli, Maharashtra 442605, India

Dr. Ulrike Streicher, Wildlife Veterinarian, Eugene, Oregon, USA

Ms. Priyanka lyer, ZOO/WILD, Coimbatore, Tamil Nadu 641035, India

Dr. BA. Daniel, $200 / \mathrm{WILD}$, Coimbatore, Tamil Nadu 641035, India

\section{Editorial Board}

Dr. Russel Mittermeie

Executive Vice Chair, Conservation International, Arlington, Virginia 22202, USA

\section{Prof. Mewa Singh Ph.D., FASc, FNA, FNASc, FNAPsy}

Ramanna Fellow and Life-Long Distinguished Professor, Biopsychology Laboratory, and Institute of Excellence, University of Mysore, Mysuru, Karnataka 570006, India; Honorary Professor, Jawaharlal Nehru Centre for Advanced Scientific Research, Bangalore; and Adjunct Professor, National Institute of Advanced Studies, Bangalore

\section{Stephen D. Nash}

Scientific Illustrator, Conservation International, Dept. of Anatomical Sciences, Health Sciences Center, T-8, Room 045, Stony Brook University, Stony Brook, NY 11794-8081, USA

\section{Dr. Fred Pluthero}

Toronto, Canada

\section{Dr. Priya Davidar}

Sigur Nature Trust, Chadapatti, Mavinhalla PO, Nilgiris, Tamil Nadu 643223, India

\section{Dr. Martin Fisher}

Senior Associate Professor, Battcock Centre for Experimental Astrophysics, Cavendish

Laboratory, JJ Thomson Avenue, Cambridge CB3 OHE, UK

\section{Dr. John Fellowes}

Honorary Assistant Professor, The Kadoorie Institute, 8/F, T.T. Tsui Building, The University of Hong Kong, Pokfulam Road, Hong Kong

\section{Prof. Dr. Mirco Solé}

Universidade Estadual de Santa Cruz, Departamento de Ciências Biológicas, Vice-coordenado do Programa de Pós-Graduação em Zoologia, Rodovia Ilhéus/Itabuna, Km 16 (45662-000)

Salobrinho, Ilhéus - Bahia - Brasil

\section{Dr. Rajeev Raghavan}

Professor of Taxonomy, Kerala University of Fisheries \& Ocean Studies, Kochi, Kerala, India

\section{English Editors}

Mrs. Mira Bhojwani, Pune, India

Dr. Fred Pluthero, Toronto, Canad

Mr. P. Ilangovan, Chennai, India

Web Development

Mrs. Latha G. Ravikumar, ZOO/WILD, Coimbatore, India

\section{Typesetting}

Mr. Arul Jagadish, ZOO, Coimbatore, India

Mrs. Radhika, ZOO, Coimbatore, India

Mrs. Geetha, ZOO, Coimbatore India
Fundraising/Communications

Mrs. Payal B. Molur, Coimbatore, India

Subject Editors 2018-2020

Fungi

Dr. B. Shivaraju, Bengaluru, Karnataka, India

Dr. R.K. Verma, Tropical Forest Research Institute, Jabalpur, India

Dr. Vatsavaya S. Raju, Kakatiay University, Warangal, Andhra Pradesh, India

Dr. M. Krishnappa, Jnana Sahyadri, Kuvempu University, Shimoga, Karnataka, India

Dr. K.R. Sridhar, Mangalore University, Mangalagangotri, Mangalore, Karnataka, India

Dr. Gunjan Biswas, Vidyasagar University, Midnapore, West Bengal, India

\section{Plants}

Dr. G.P. Sinha, Botanical Survey of India, Allahabad, India

Dr. N.P. Balakrishnan, Ret. Joint Director, BSI, Coimbatore, India

Dr. Shonil Bhagwat, Open University and University of Oxford, UK

Prof. D.J. Bhat, Retd. Professor, Goa University, Goa, India

Dr. Ferdinando Boero, Università del Salento, Lecce, Italy

Dr. Dale R. Calder, Royal Ontaro Museum, Toronto, Ontario, Canada

Dr. Cleofas Cervancia, Univ. of Philippines Los Baños College Laguna, Philippines

Dr. F.B. Vincent Florens, University of Mauritius, Mauritius

Dr. Merlin Franco, Curtin University, Malaysia

Dr. V. Irudayaraj, St. Xavier's College, Palayamkottai, Tamil Nadu, India

Dr. B.S. Kholia, Botanical Survey of India, Gangtok, Sikkim, India

Dr. Pankaj Kumar, Kadoorie Farm and Botanic Garden Corporation, Hong Kong S.A.R., China

Dr. V. Sampath Kumar, Botanical Survey of India, Howrah, West Bengal, India

Dr. A.J. Solomon Raju, Andhra University, Visakhapatnam, India

Dr. Vijayasankar Raman, University of Mississippi, USA

Dr. B. Ravi Prasad Rao, Sri Krishnadevaraya University, Anantpur, India

Dr. K. Ravikumar, FRLHT, Bengaluru, Karnataka, India

Dr. Aparna Watve, Pune, Maharashtra, India

Dr. Qiang Liu, Xishuangbanna Tropical Botanical Garden, Yunnan, China

Dr. Noor Azhar Mohamed Shazili, Universiti Malaysia Terengganu, Kuala Terengganu, Malaysia

Dr. M.K. Vasudeva Rao, Shiv Ranjani Housing Society, Pune, Maharashtra, India

Prof. A.J. Solomon Raju, Andhra University, Visakhapatnam, India

Dr. Mandar Datar, Agharkar Research Institute, Pune, Maharashtra, India

Dr. M.K. Janarthanam, Goa University, Goa, India

Dr. K. Karthigeyan, Botanical Survey of India, India

Dr. Errol Vela, University of Montpellier, Montpellier, France

Dr. P. Lakshminarasimhan, Botanical Survey of India, Howrah, India

Dr. Larry R. Noblick, Montgomery Botanical Center, Miami, USA

Dr. K. Haridasan, Pallavur, Palakkad District, Kerala, India

Dr. Analinda Manila-Fajard, University of the Philippines Los Banos, Laguna, Philippines

Dr. P.A. Sinu, Central University of Kerala, Kasaragod, Kerala, India

Dr. Afroz Alam, Banasthali Vidyapith (accredited A grade by NAAC), Rajasthan, India

Dr. K.P. Rajesh, Zamorin's Guruvayurappan College, GA College PO, Kozhikode, Kerala, India

Dr. David E. Boufford, Harvard University Herbaria, Cambridge, MA 02138-2020, USA

Dr. Ritesh Kumar Choudhary, Agharkar Research Institute, Pune, Maharashtra, India

Dr. Navendu Page, Wildlife Institute of India, Chandrabani, Dehradun, Uttarakhand, India

\section{Invertebrates}

Dr. R.K. Avasthi, Rohtak University, Haryana, India

Dr. D.B. Bastawade, Maharashtra, India

Dr. Partha Pratim Bhattacharjee, Tripura University, Suryamaninagar, India

Dr. Kailash Chandra, Zoological Survey of India, Jabalpur, Madhya Pradesh, India

Dr. Ansie Dippenaar-Schoeman, University of Pretoria, Queenswood, South Africa

Dr. Rory Dow, National Museum of natural History Naturalis, The Netherlands

Dr. Brian Fisher, California Academy of Sciences, USA

Dr. Richard Gallon, llandudno, North Wales, LL30 1UP

Dr. Hemant V. Ghate, Modern College, Pune, India

Dr. M. Monwar Hossain, Jahangirnagar University, Dhaka, Bangladesh

Mr. Jatishwor Singh Irungbam, Biology Centre CAS, Branišovská, Czech Republic.

Dr. Ian J. Kitching, Natural History Museum, Cromwell Road, UK

Dr. George Mathew, Kerala Forest Research Institute, Peechi, India

For Focus, Scope, Aims, and Policies, visit https://threatenedtaxa.org/index.php/JoTT/aims_scope
For Article Submission Guidelines, visit https://threatenedtaxa.org/index.php/JoTT/about/submissions
For Policies against Scientific Misconduct, visit https://threatenedtaxa.org/index.php/JoTT/policies_various 


\title{
Observations on the foraging behavior of Tricoloured Munia Lonchura malacca (Linnaeus, 1766) and its interaction with pearl millet fields in Villupuram District, Tamil Nadu, India
}

\author{
M. Pandian (D) \\ No. F1901, Taisha, Natesan Nagar West, Virugambakkam, Chennai, Tamil Nadu 600092, India. \\ pandian.m14@gmail.com
}

\begin{abstract}
Study of foraging behaviour of Tricoloured Munia Lonchura malacca and its interaction in pearl millet crop fields was conducted in six villages of Tindivanam taluk, Villupuram district, Tamil Nadu from April to June 2020. A total of six flocks containing 1,640 birds of Tricoloured Munia were enumerated. The number of birds per flock varied from 60 to 800 . They never split into small flocks and maintained the same flock size throughout the day. Tricoloured Munias used nine plant species for roosting. Twelve quadrats ( $0.3 \mathrm{ha})$ each of $5 \mathrm{~m} \times 5 \mathrm{~m}$ size were laid in the pearl millet fields covering six villages. A total of 10,295 spikes were counted in these plots, and of these 3,785 spikes (36.7\%) were found damaged by foraging munias. The maximum damage of $99.6 \%$ was observed in Thenputhur village. Along with Tricoloured Munia, five other granivorous birds, such as Baya Weaver Ploceus philippinus, Indian Silverbill Euodice malabarica, Common Babbler Turdoides caudata, Rose-ringed Parakeet Psittacula krameri, and White-rumped Munia Lonchura striata were also found foraging without any inter-specific competition. Farmers adopted various traditional bird repellent techniques such as beating utensils, throwing pebbles/soil on the crop, placing scarecrows, tying multi-coloured ribbons, and hanging bottles to chase the birds away.
\end{abstract}

Keywords: Bird repellent, flocking behaviour, granivorous birds, inter-specific competition, roosting plants.

Citation: Pandian, M. (2021). Observations on the foraging behavior of Tricoloured Munia Lonchura malacca (Linnaeus, 1766) and its interaction with pearl millet fields in Villupuram District, Tamil Nadu, India. Journal of Threatened Taxa 13(14): 20201-20208. https://doi.org/10.11609/jott.6329.13.14.20201-20208

Copyright: (c) Pandian 2021. Creative Commons Attribution 4.0 International License. JoTT allows unrestricted use, reproduction, and distribution of this article in any medium by providing adequate credit to the author(s) and the source of publication.

Funding: None.

Competing interests: The author declares no competing interests.

Author details: M. PANDIAN has completed MSc., PhD., in Botany and BLIS from University of Madras and Bachelor of Education (BEd) from Annamalai University, Chidambaram and now serves in Tamil Nadu Police Department. His area of interest is ecology and nesting biology of birds and published a few papers on House Sparrows, Baya Weavers, Munias, Ring-necked Parakeets, and Indian Flying Fox.

Acknowledgements: I thank D. Balaji (Villupuram), S. Kamarajan (Minnal), and V. Sumathi (Chennai) for assistance in data collection, S. Suresh, Assistant Professor (University of Madras), and A. Giridharan (Minnal) for help with data analysis and photography. 


\section{INTRODUCTION}

The Tricoloured Munia Lonchura malacca (Aves: Passeriformes: Estrildidae) is a small, finch-like, granivorous bird. It is native to India and Sri Lanka and was introduced into Costa Rica, Haiti, Venezuela, Japan, Jamaica, and Portugal (BirdLife International 2018). This species is considered endemic to the Indian subcontinent and distributed in the Peninsula from Gujarat to Sri Lanka (Ali \& Ripley 1987; Grimmet et al. 1999; Rasmussen \& Anderton 2005). Tricoloured Munia population is adaptable to a wide range of habitats such as open agricultural lands, woodlands, grasslands, and scrub lands. The global population size of this species has not been quantified by BirdLife International. The IUCN Red List classified this species as 'Least Concern' (BirdLife International 2018). Though this species is widely distributed in the dry plains of India, only a few authors have recorded the presence of this species in Carnatic region (Cole \& Brown 1840), and recent records of the species is from Karur (Salahudeen et al. 2013; Deepan et al. 2017), Coimbatore (Daniel 2017), Villupuram districts, and a few records are from Rajasthan as well (Jamdar 1998; Sharma 1999; Bhatnagar 2013) (https:// ebird.org/species/trimun).

India is a major producer of pearl millet (Pennisetum glaucum (L.) R. Br.) and 83\% of the country's production occurs in Rajasthan, followed by Uttar Pradesh, Gujarat, and Haryana (www.millets.dactw.nic.in). In Villupuram district of Tamil Nadu is the major producer of pearl millet (Agricultural Times 2016).

Incidents of flocks of $L$. malacca gleaning grains in paddy fields were reported in Colombia (Cubillos et al. 2010), Philippines (Llaguno 1975; Reidinger \& Libay 1979), and Rajasthan (Bhatnagar et al. 2013). Literature survey revealed that studies are not available on the foraging behaviors of $L$. malacca and its interaction with pearl millet crop fields. Hence, to fill this gap, I decided to take up a study on foraging and roosting behaviors of $L$. malacca and its interaction with pearl millet crop fields in Tindivanam taluk, Villupuram district, Tamil Nadu.

\section{MATERIALS AND METHODS}

\section{Study Area}

The present study was carried out in six villages viz., Thenputhur, Pathirapuliyur, Elayandapattu, Veedur, Mozhiyanur, and Nedi in Tindivanam taluk in Villupuram district (11.939 N, 79.492 E) of northeastern
Tamil Nadu (Figure 1). The district spreads over 3,715 $\mathrm{km}^{2}$, with a human population of c. 20,90,000 (Figure 1 ; www.viluppuram.nic.in). Agriculture is the primary occupation of the people. The major crops of the area are paddy Oryza sativa L., jowar Sorghum bicolor (L.) Moench., pearl millet Pennisetum glaucum (L.) R.Br., finger millet Eleusine coracana Gaertn., sugarcane Saccharum officinarum L., groundnut Arachis hypogaea L., and green gram Vigna radiata (L.) R.Wilczek. The maximum and minimum temperatures in the district are $36^{\circ} \mathrm{C}$ and $20^{\circ} \mathrm{C}$, respectively and the average annual rainfall is $1,060 \mathrm{~mm}$ (www.viluppuram.nic.in).

\section{Methods}

Based on information from two persons, suitable habitats were identified, where significant population of Tricoloured Munia persists in six villages of Tindivanam taluk of Villupuram district. These habitats were surveyed from April to June 2020 between 0545 and $1000 \mathrm{~h}$, and again between 1500 and $1800 \mathrm{~h}$, when the birds are usually active during pearl millet cultivation in Villupuram district usually commences, i.e., Chithiraipattam every year sowing in March-April and harvest in MayJune. Hence, I have selected this period for study. The number of individual birds on foraging and roosting sites was determined using total count method (Bibby et al. 2000). A total count of individuals of this species was taken when the birds were in foraging and roosting sites. Tricoloured Munia usually live as a flock, roost on nearby vegetation in croplands during night, and move immediately after sunrise around adjacent croplands searching for food. Hence, the number of birds in each flock was counted when they were roosting and foraging. The foraging behaviors, movements of each flock and inter-specific relationships with other granivorous birds were observed in each village continuously for three days using binoculars without causing any disturbance to the birds. The types of trees/shrubs/herbs used by birds for roosting were ascertained. An extent of twoacres of pearl millet crop fields was randomly selected in each of the six villages. A total of twelve acres of pearl millet crop fields were selected for random sampling. Two $5 \mathrm{~m} \times 5 \mathrm{~m}$ size quadrats / plots were laid in the selected sites, i.e., two plots per village. Out of the two plots, one was along the edge of crop field and while the other was in the interior of the field. The number of spikes and the number of damaged spikes in each quadrat were manually counted. The time spent by each flock on crop while foraging was measured using the stopwatch feature in smart phones. The exact locations of the croplands where foraging activities of 


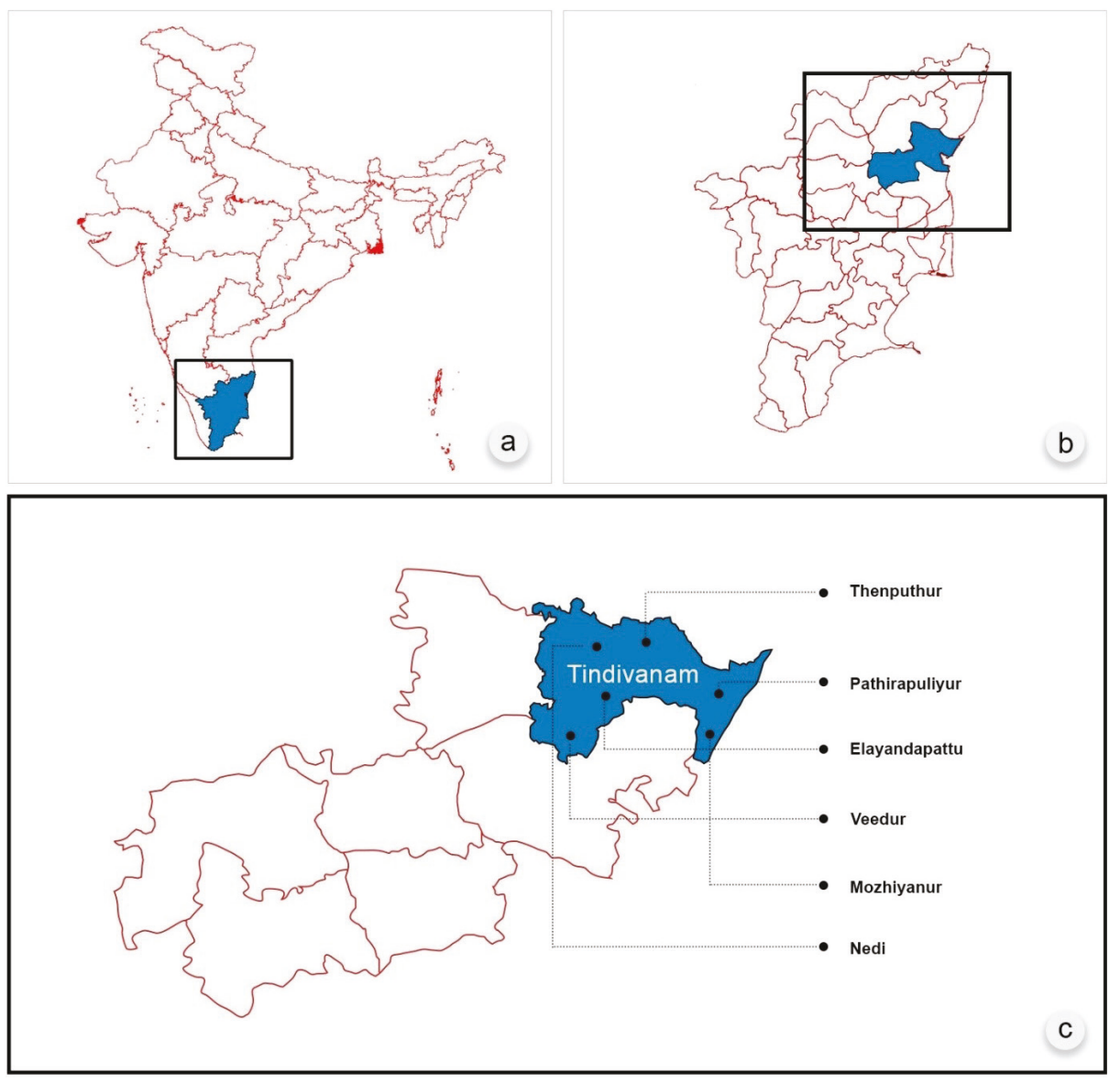

Figure 1. Study area map: a-India map showing Tamil Nadu | b-Tamil Nadu map showing Villupuram district | c-Villupuram district map showing Tindivanam taluk and villages studied. List of villages are (1) Thenputhur $\left(12.177^{\circ} \mathrm{N}, 79.549^{\circ} \mathrm{E}\right),(2)$ Pathirapuliyur $\left(12.177^{\circ} \mathrm{N}, 79.549^{\circ} \mathrm{E}\right)$, (3) Elayandapattu $\left(12.023^{\circ} \mathrm{N}, 79.604^{\circ} \mathrm{E}\right),(4)$ Veedur $\left(12.059^{\circ} \mathrm{N}, 79.598^{\circ} \mathrm{E}\right),(5)$ Mozhiyanur $\left(12.148^{\circ} \mathrm{N}, 79.552^{\circ} \mathrm{E}\right)$, and $(6)$ Nedi $\left(12.116^{\circ} \mathrm{N}, 79.576^{\circ} \mathrm{E}\right)$.

birds occurred were noted using Garmin Etrex 20x GPS device. Photographs and videos were taken using Nikon P1000 digital camera. The bird repellent techniques were recorded by direct observations in the crop fields in six villages. No questionnaire survey was done in this regard. The collected data were tabulated, analyzed and shown as graphical representation.

\section{RESULTS AND DISCUSSION}

A total of six flocks of Tricoloured Munia, one each in each village were identified. A total of 1,640 individuals of Tricoloured Munia were enumerated (Table 1). In addition to flocks of Tricoloured Munia, other granivorous species, such as Baya Weaver (240), Indian Silverbill (26), Common Babbler (19), Rose-ringed Parakeet (11), and White-rumped Munia (8) were also found foraging in pearl millet crop fields. The smallest flock size was 60 birds in Nedi village, while the largest of 800 birds was recorded in Thenputhur village (Table 1).

The study on the behavior of the flocks reveals that the individuals of Tricoloured Munia strictly followed communal roosting and foraging. During the entire study period, the existing flocks never split into many smaller groups. They moved as flocks from morning to evening and maintained the flock size throughout the day. The flock size varies from village to village (Table 2). The flocking behavior varies and the birds took various complicated formations to reach pearl millet crops as well as roosting sites. It was observed that the flocks fly in close formations by performing different manoeuvres. They commence their daily foraging between $0545 \mathrm{~h}$ and $0615 \mathrm{~h}$ and conclude their foraging before 1800 h. No foraging activities were observed between 1130 $\mathrm{h}$ and $1500 \mathrm{~h}$, when the flocks moved to adjacent vegetations for roosting. Continuous observations on the movements of the flock in each village consecutively for three days revealed that the birds never go beyond 
Table 1. Details of quadrats, number of flocks, number of birds per flock, and damages to spikes of pearl millet in the study area.

\begin{tabular}{|c|c|c|c|c|c|c|c|c|}
\hline & $\begin{array}{l}\text { Name of the } \\
\text { village }\end{array}$ & $\begin{array}{c}\text { Total } \\
\text { Cultivated area } \\
\text { (acres) studied }\end{array}$ & $\begin{array}{c}\text { No. of } \\
\text { quadrats laid } \\
(5 \mathrm{~m} \times 5 \mathrm{~m})\end{array}$ & No. of flocks & $\begin{array}{c}\text { No. of birds in } \\
\text { a flock }\end{array}$ & $\begin{array}{l}\text { Total no. spikes } \\
\text { counted }\end{array}$ & $\begin{array}{c}\text { Total no } \\
\text { of spikes } \\
\text { damaged }\end{array}$ & $\begin{array}{c}\text { Percentage } \\
\text { of damaged } \\
\text { spikes }\end{array}$ \\
\hline 1 & Thenputhur & 2 & 2 & 1 & 800 & 1596 & 1564 & $99.6 \%$ \\
\hline 2 & Pathirapuliyur & 2 & 2 & 1 & 180 & 1850 & 298 & $16.1 \%$ \\
\hline 3 & Elayandapattu & 2 & 2 & 1 & 300 & 1810 & 485 & $26.7 \%$ \\
\hline 4 & Veedur & 2 & 2 & 1 & 200 & 1560 & 450 & $28.8 \%$ \\
\hline 5 & Mozhiyanur & 2 & 2 & 1 & 100 & 1680 & 473 & $28.1 \%$ \\
\hline 6 & Nedi & 2 & 2 & 1 & 60 & 1795 & 515 & $28.6 \%$ \\
\hline & Total & 12 & 12 & 6 & 1640 & 10291 & 3785 & $36.7 \%$ \\
\hline
\end{tabular}

a $2-\mathrm{km}$ radius from the targeted two-acres pearl millet crop. A total of 104 foraging visits of flocks were studied in the six villages. The mean number of visits to pearl millet crop was 10 in the forenoon (0545-1000 h), and seven in the afternoon (1500-1800 h). The total number of foraging visits to crops per day varies from a minimum of 11 to a maximum of 21 . In each foraging visit, they stay on the spikes from $10 \mathrm{sec}$ to $80 \mathrm{sec}$, glean millets and take sudden flight to adjacent places for temporary roosting. Analysis of the duration over the 104 foraging visits showed that the maximum number of visits fell between two duration segments: 41 to 50 , and 51 to 60 sec, which accounted for $43.6 \%$ of the total visits. This indicates that the optimum time the birds preferred to spend and forage on the crop fields was around 50 seconds (Table 2; Figure 2).

The foraging flocks roost temporarily on powerline cables that cross the crop fields. During non-foraging periods and nights, they use nearby vegetations as roosting sites. This bird uses nine species of plants for roosting. They are: Prosopis juliflora (Sw.) DC., Lantana camara L., Canthium coromandelicum L., Pithecellobium dulce (Roxb.) Benth., Abutilon indicum (Link) Sweet., Azadirachta indica A.Juss., Vachellia nilotica (L.) P.J.H.Hurter \& Mabb., Saccharum officinarum L., and Sorghum bicolor (L.) Moench. The duration of stay of this bird on spikes is short as compared to the duration spent roosting on trees / shrubs / herbs. The reason could be that being habituated to disturbance caused by farmers by banging utensils or other means to chase them away from crops, the birds avoid stay on the crops for long duration while foraging. Threat of prolonged exposure to predators while foraging on open crop fields could be another reason. According to eBird India (www.ebird.org), about 21 avian predators occur in Villupuram district. But the common predators observed during the present study in six villages were

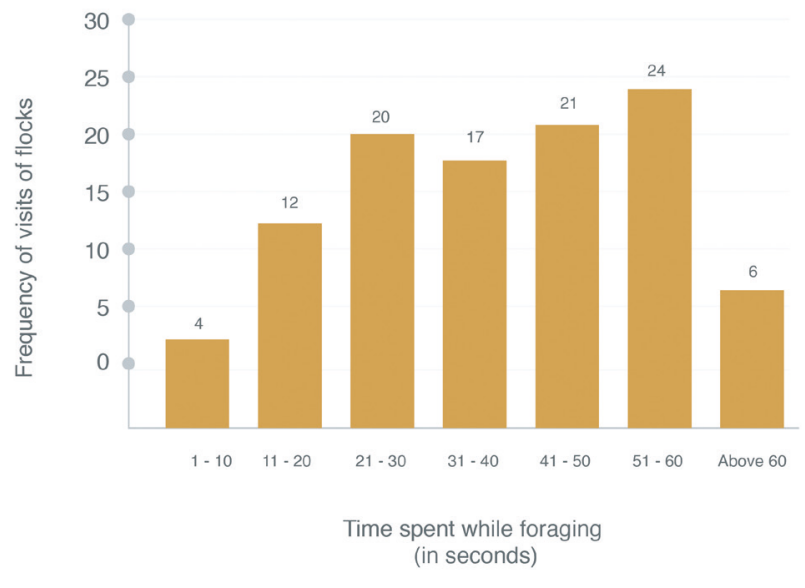

Figure 2. Frequency of foraging visits of flocks and time spent on crops for foraging.

House Crow Corvus splendens, Large-billed Crow Corvus macrorhynchos, Shikra Accipiter badius, Sparrowhawk Accipiter nisus, White-eyed Buzzard Butastur teesa, and Rufous Treepie Dendrocitta vagabunda. Gadgil \& Ali (1975) stated that the habit of communal roosting helps them to communicate information about source of food and protection from predators. The present observation of huge flock size, communal roosting pattern and foraging enmasse on pearl millet crops probably helps to exchange information about source of food and approach of predators as stated by Gadgil \& Ali (1975).

Pearl millet is a 90-day crop and maturing kernels start after 60 days of sowing. The study reveals that the flocks started to visit the spikes after the $65^{\text {th }}$ day when the grains were in milky stage and continued their visit to the crop till harvesting. Frequent attacks on the crops and gleaning of the grains leave the spikes devoid of grains (Image 1). In order to assess the extent of damage to grains in the spikes, a total of 10,295 spikes were sampled in all the 12 quadrats 
Table 2. Details of different species of birds, numbers, mean visits and duration of foraging in the study area.

\begin{tabular}{|c|c|c|c|c|c|c|c|c|c|c|}
\hline & \multirow[b]{2}{*}{$\begin{array}{l}\text { Name of the } \\
\text { village }\end{array}$} & \multirow[b]{2}{*}{$\begin{array}{c}\text { No. of } \\
\text { flock }\end{array}$} & \multirow[b]{2}{*}{$\begin{array}{c}\text { No. of } \\
\text { Tricoloured } \\
\text { Munia in } \\
\text { the flock }\end{array}$} & \multicolumn{5}{|c|}{ Other granivorous birds } & \multirow[b]{2}{*}{$\begin{array}{l}\text { Mean no. } \\
\text { of visits to } \\
\text { crop per } \\
\text { day }\end{array}$} & \multirow[b]{2}{*}{$\begin{array}{l}\text { Duration o } \\
\text { foraging in } \\
\text { each visit } \\
\text { (seconds) }\end{array}$} \\
\hline & & & & $\begin{array}{l}\text { No. of } \\
\text { White- } \\
\text { rumped } \\
\text { Munia }\end{array}$ & $\begin{array}{l}\text { No. of Baya } \\
\text { Weaver }\end{array}$ & $\begin{array}{c}\text { No. of } \\
\text { Rose- } \\
\text { ringed } \\
\text { Parakeet }\end{array}$ & $\begin{array}{c}\text { No. of } \\
\text { Yellow } \\
\text { Common } \\
\text { Babbler }\end{array}$ & $\begin{array}{l}\text { Indian } \\
\text { Silver bill }\end{array}$ & & \\
\hline 1 & Thenputhur & 1 & 800 & 3 & 40 & 6 & 8 & 7 & 18 & $10-70$ \\
\hline 2 & Pathirapuliyur & 1 & 180 & 2 & 30 & 0 & 0 & 4 & 21 & $10-70$ \\
\hline 3 & Elayandapattu & 1 & 300 & 0 & 50 & 2 & 5 & 11 & 19 & $20-60$ \\
\hline 4 & Veedur & 1 & 200 & 0 & 30 & 1 & 6 & 2 & 18 & $20-60$ \\
\hline 5 & Mozhiyanur & 1 & 100 & 0 & 60 & 0 & 0 & 0 & 18 & $10-60$ \\
\hline 6 & Nedi & 1 & 60 & 3 & 30 & 2 & 0 & 2 & 11 & $20-80$ \\
\hline & Total & 6 & 1640 & 8 & 240 & 11 & 19 & 26 & - & \\
\hline
\end{tabular}

(0.3 ha) in six villages and among them, $36.7 \%$ spikes $(n=3,785)$ were found damaged by Tricoloured Munia. Out of 12 quadrats, six quadrats were laid towards the margin of the field and another six quadrats were laid in inner side of the field. Analysis reveals that out of a total $36.7 \%$ damages to spikes $(3,785)$, more damages to spikes (1,960 spikes; $19 \%)$ were found in the inner side and less damages were reported to spikes $(1,825$ spikes;17.7\%) occurred towards the peripheral region. It indicates that the birds avoid perching and foraging on the peripheral parts of the field. The reason could be the frequent visits of farmers along the bunds and roads and chasing the birds using traditional bird repellent techniques. The maximum damage was observed in Thenputhur (99.6\%), followed by Veedur (28.8\%), Nedi (28.6), Mozhiyanur (28.1\%), Elayandapattu (26.7\%), and Pathirapuliyur (16.1). Out of the 1,596 spikes counted in two quadrats (total $50 \mathrm{~m}^{2}$ area) in this village, 1,564 spikes (99.6\%) were found damaged. Reason for the greater percentage of damage could be the availability of sugarcane crops in the adjacent land which provide conducive habitat to the flock for roosting during nonforaging periods and to hide when the farmers chase them away from pearl millet crop. On the $90^{\text {th }}$ day, almost all the spikes in the two-acre land in Thenputhur village were found devoid of any grains and hence, the land holder ploughed the land without harvesting the empty spikes. Hence, foraging was found to cause nearly $100 \%$ losses of grains in the two-acre crop. According to the Directorate of Millets Development, the yield of pearl millet grains per acre (rainfed land) in India is c.485 to $600 \mathrm{~kg}$ (www.millets.dactv.nic.in). The loss of grains in two-acre crop in Thenputhur village would be $1,942 \mathrm{~kg}$ to $2,428 \mathrm{~kg}$. But in the remaining five villages the damage to spikes was found to be only between $16.1 \%$ and $28.8 \%$. This could be because of the small flock size consisting of birds ranging in number from 60 to 300. Kale et al. (2012) had stated that in India, the damage to pearl millet and sorghum crops by birds is a major concern. The present study on loss of pearl millet grains by granivorous birds matches the findings of Kale et al. (2012) that the loss of pearl millet crop by birds is a major concern.

The study reveals that among the foraging flocks of Tricoloured Munia, a few individuals of other granivorous birds such as Baya Weaver Ploceus philippinus, Roseringed Parakeet Psittacula krameri, Common Babbler Turdoides caudata, White-rumped Munia Lonchura striata, and Indian Silverbill Euodice malabarica were also observed in the pearl millet crops (Image 2a,b,c). Inter-specific competition between Tricoloured Munia and other species during foraging on pearl millet crops was not observed during the study period (Table 2). Rao \& Dubey (2006) had stated that Rose-ringed Parakeet, Baya Weaver, Indian Silverbill, Common Babbler, Common Myna (Acridotheres tristis), and Lonchura spp had caused considerable damage to the pearl millet crops in Gujarat (0.3\% to $40 \%)$, Andhra Pradesh (1.5\% to 9\%), Punjab (4\% to 5\%), and Delhi (60\%). In the present study also, it was observed that along with flocks of Tricoloured Munia, other granivorous species such as Baya Weaver (240), Indian Silverbill (26), Common Babbler (19), Roseringed Parakeet (11), and White-rumped Munia (8) were also foraging on pearl millet crops and hence this matches the findings of Rao \& Dubey (2006). It indicates that all these granivorous species co-exist and forage on targeted crops in the agricultural ecosystem without any inter-specific competitions between them over sharing of food. Further quantitative study in a wider area is required to estimate the exact extent of damage caused to grain production per hectare by these granivorous birds (Image 1; Image 2a,b,c). 

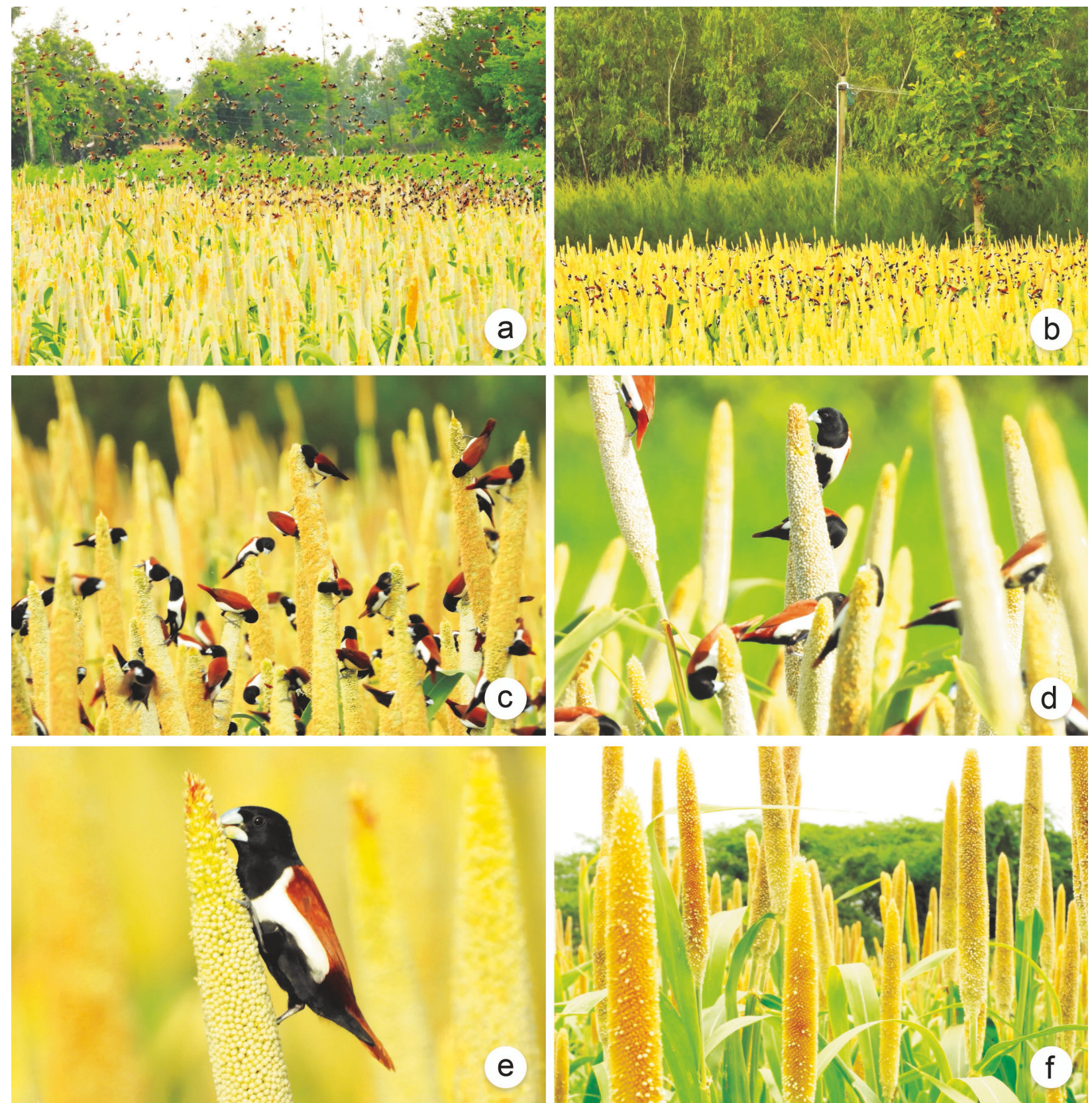

Image 1. Pictures of Lonchura malacca in pearl millet crop fields: a \& b-Flock attacking pearl millet crop | c \& e-Flock perched on spikes and gleaning grains | d-Individual bird gleaning grains | $\mathrm{f}-$ Spikes devoid of grains. (C) M. Pandian

\section{Bird repelling techniques adopted by farmers}

Techniques used to repel birds from crops in the six villages reveals that farmers had uniformly adopted the practices of beating utensils / iron barrels and throwing pebbles / soil randomly on the crops to chase the birds from morning to evening except the period from 1200 $\mathrm{h}$ to $1500 \mathrm{~h}$ when the birds were usually non-active. In Nedi village, the farmers tied reflective multi-coloured pieces of cloth on dry twigs and erected them in the fields. In Thenputhur village, empty bottles were hung by strings to make noises when wind causes them to collide with each other. Two scarecrow structures each in the shape of human figures were found fixed in the crop fields in Veedur and Nedi villages. Subramanya (1982) had stated that farmers in India use shining ribbons, noise making devices, and scarecrows to repel birds from crop lands. The present observation of farmers using scarecrows, multi-coloured ribbons, and making noise by beating utensils / iron barrels as bird repellent techniques matches with the observations 

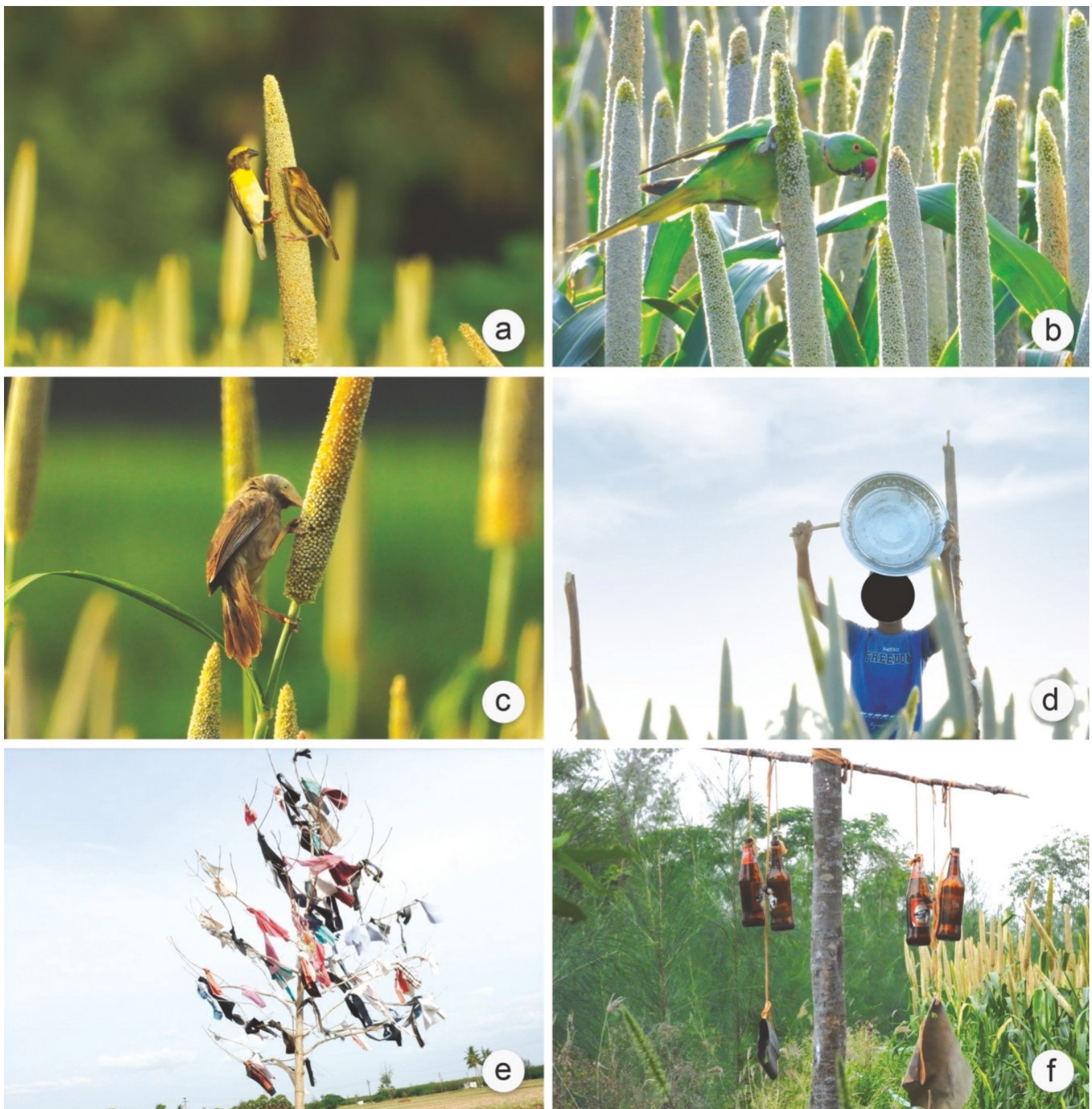

Image 2. Pictures showing forage and bird repellent methods used by farmers: a-Pair of foraging Ploceus philippinus | b-Foraging Psittacula Krameri individual | c-Turdoides caudata pluck grains | d-Beating of utensil | e-Multi-coloured ribbons tied to twigs | h-Hanging empty bottles. (c) M. Pandian

of Subramanya (1982). Even after adoption of these traditional techniques by farmers, the flocks containing Tricoloured Munia and other granivorous birds had attacked the crops and caused loss of grain productions in the study area (Image 2c,d,e). Hence, a detailed study is required on the impact of various traditional bird repellent techniques on the flocks. No incidents of killing of birds or use of any lethal techniques against granivorous birds were observed in the study area. This shows that even after undergoing economic loss due to the birds, the farmers had eco-friendly attitude by not harming the birds.

\section{CONCLUSION}

A total of 1,640 individuals of Tricoloured Munia were counted in six flocks covering six villages. 
Tricoloured Munia caused damages to the spikes ranging from $16.1 \%$ to $99.6 \%$ resulting in economic loss to the farmers. Other granivorous birds such as Baya Weaver, Rose-ringed Parakeet, Common Babbler, White-rumped Munia, and Indian Silverbill were also found foraging along with Tricoloured Munia. This indicates that the region provides a suitable habitat to diverse avifauna. Further quantitative study in a wider area is required to estimate the exact extent of damage caused to grain production per hectare by these granivorous birds. Based on my observations, the following measures are proposed:

(a) Local community, particularly land holders, and agricultural workers should be sensitized to understand the need to preserve the precious populations of avifauna.

(b) A detailed systematic survey on the population status, behavior of flocks and impact of these birds on the pearl millet crops covering the entire state may be carried out to help in drafting an action plan to conserve the avifauna of agro-ecosystem.

(c) Eco-friendly approaches by using traditional and non-lethal techniques have to be adopted for protecting pearl millet crops from depredatory birds. (d) Efforts must be taken to study birds' habitat and formulate policies to reduce bird-farmer conflicts and promote biodiversity conservation.

\section{REFERENCES}

Agriculture Times (2016). Pearl millet price will be static, Estimates, TNAU. www.agritimes.co.in (Accessed on 21 June 2020).

Ali, S. \& S.D. Ripley (1987). Birds of India and Pakistan. Oxford University Press, New Delhi. 890 pp.

Bhatnagar, C., D.S. Shekhawat \& V.K. Kohli (2013). Second record of the Tricolored Munia Lonchura malacca from southern Rajasthan. Journal of the Bombay Natural History Society 110(1): 76.

Bibby C.J., N.D. Burgess, D.A. Hill \& S.H. Mustoe (2000). Bird Census Techniques. Second Edition. Academic Press, London, UK, xvii+302pp.

BirdLife International (2018). Lonchura malacca. The IUCN Red List of Threatened Species. Accessed on 09 June 2020. www.iucnredlist. org/species/22719837/131885437
Cole, R. \& C.P. Brown (1840). Catalogue of the Birds. The Madras Journal of Literature and Science 11: 27.

Cubillos, C.K., D.C. Ayala, R.M.P. Hernandez, M.M. Palacios, C.D. Jaranillo \& J.S. Mejia (2010). Feeding biology of the tricolored munia (Lonchura malacca, Estrildidae) in the upper Magdalena valley, Colombia. Ornithologia Colombiana 9: 25-30.

Daniel, A.J. (2017). Commonly found avifauna of Tamil Nadu Agricultural University, Coimbatore, Tamil Nadu, India. Journal of Entomology and Zoological Studies 5 (4): 46-52.

Deepan, R., B. Vikram, B. Harish, B. Ramakrishnan \& A. Samson (2017). Occurrence of Tricoloured Munia (Lonchura malacca) in Karur district, Tamil Nadu. Journal of Applied Science and Research 5(6): $79-80$.

Gadgil, M. \& S. Ali (1975). Communal Roosting habits of Indian Birds. Journal of the Bombay Natural History Society 72(3): 716-726.

Grimmett, R., C. Inskipp \& T. Inskipp (1999). Birds of the Indian Subcontinent. Oxford University Press, Delhi, India, 480 pp.

Jamdar, N. (1998). Southern black-headed munia Lonchura malacca in Koladeo National Park, Bharatpur, Rajasthan. Journal of the Bombay Natural History Society 95(3): 509-510.

Kale, M., B. Balfors, U. Mortberg, P. Bhattacharya \& S. Chakane (2012). Damage to agricultural yield due to farmland birds, present repelling techniques and its impacts: an insight from the Indian perspective. Journal of Agricultural Technology 8(1): 49-62.

Llaguno, G.V. (1975). Damage potential of three species of Philippine weavers (Lonchura), Kaliskaran, Philippines. Journal of Biology 4: 141-144.

Rao, V. \& O.P. Dubey (2006). Granivorous bird pests and their management. pp 29-61. In: S. Sridhara (Ed.), Vertebrate pests in Agriculture-Indian Scenario. Scientific Publishers, Jodhpur, India.

Rasmussen, P.C. \& J.C. Anderton (2005). The Birds of South Asia: The Ripley Guide, 2 Volumes, Smithsonian Institute, Washington, D. C. \& Lynx Edicions, Barcelona, 1067 pp.

Reidinger, R.F. \& J.L. Libay (1979). Perches coated with glue reduce damage in rice field plots. Bird Control Seminars Proceedings, 26. Wildlife Damage Management. University of Nebraska-Lincoln, Nov 1979.

Salahudeen, M., E. Saranya, C. Gunasekaran \& C. Vadivalagan (2013). Studies on the abundance and distribution of birds in three different habitats of Karur district, Tamil Nadu, South India. Journal of the Bombay Natural History Society 1(3): 57-63.

Sharma, S.K. (1999). Range extension of southern Black-headed Munia Lonchura malacca. Journal of the Bombay Natural History Society 38(2): $25-27$.

Subramanya, S. (1982). Non-random foraging in certain bird pests of field crops. Journal of Biosciences 19(4): 369-380.

www.viluppuram.nic.in (2020). Government of Tamil Nadu: Villupuram District wbsite www.viluppursm.nic.in (Accessed on 09 June 2020).

www.viluppursm.nic.in (2020). Directorate of Millet Development, Government of India Website www.viluppursm.nic.in (accessed on 09 June 2020).

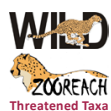


Dr. John Noyes, Natural History Museum, London, UK

Dr. Albert G. Orr, Griffith University, Nathan, Australia

Dr. Sameer Padhye, Katholieke Universiteit Leuven, Belgium

Dr. Nancy van der Poorten, Toronto, Canada

Dr. Kareen Schnabel, NIWA, Wellington, New Zealand

Dr. R.M. Sharma, (Retd.) Scientist, Zoological Survey of India, Pune, India

Dr. Manju Siliwal, WILD, Coimbatore, Tamil Nadu, India

Dr. G.P. Sinha, Botanical Survey of India, Allahabad, India

Dr. K.A. Subramanian, Zoological Survey of India, New Alipore, Kolkata, India

Dr. P.M. Sureshan, Zoological Survey of India, Kozhikode, Kerala, India

Dr. R. Varatharajan, Manipur University, Imphal, Manipur, India

Dr. Eduard Vives, Museu de Ciències Naturals de Barcelona, Terrassa, Spain

Dr. James Young, Hong Kong Lepidopterists' Society, Hong Kong

Dr. R. Sundararaj, Institute of Wood Science \& Technology, Bengaluru, India

Dr. M. Nithyanandan, Environmental Department, La Ala Al Kuwait Real Estate. Co. K.S.C.,

Kuwait

Dr. Himender Bharti, Punjabi University, Punjab, India

Mr. Purnendu Roy, London, UK

Dr. Saito Motoki, The Butterfly Society of Japan, Tokyo, Japan

Dr. Sanjay Sondhi, TITLI TRUST, Kalpavriksh, Dehradun, India

Dr. Nguyen Thi Phuong Lien, Vietnam Academy of Science and Technology, Hanoi, Vietnam

Dr. Nitin Kulkarni, Tropical Research Institute, Jabalpur, India

Dr. Robin Wen Jiang Ngiam, National Parks Board, Singapore

Dr. Lional Monod, Natural History Museum of Geneva, Genève, Switzerland.

Dr. Asheesh Shivam, Nehru Gram Bharti University, Allahabad, India

Dr. Rosana Moreira da Rocha, Universidade Federal do Paraná, Curitiba, Brasi

Dr. Kurt R. Arnold, North Dakota State University, Saxony, Germany

Dr. James M. Carpenter, American Museum of Natural History, New York, USA

Dr. David M. Claborn, Missouri State University, Springfield, USA

Dr. Kareen Schnabel, Marine Biologist, Wellington, New Zealand

Dr. Amazonas Chagas Júnior, Universidade Federal de Mato Grosso, Cuiabá, Brasil

Mr. Monsoon Jyoti Gogoi, Assam University, Silchar, Assam, India

Dr. Heo Chong Chin, Universiti Teknologi MARA (UiTM), Selangor, Malaysia

Dr. R.J. Shiel, University of Adelaide, SA 5005, Australia

Dr. Siddharth Kulkarni, The George Washington University, Washington, USA

Dr. Priyadarsanan Dharma Rajan, ATREE, Bengaluru, India

Dr. Phil Alderslade, CSIRO Marine And Atmospheric Research, Hobart, Australia

Dr. John E.N. Veron, Coral Reef Research, Townsville, Australia

Dr. Daniel Whitmore, State Museum of Natural History Stuttgart, Rosenstein, Germany.

Dr. Yu-Feng Hsu, National Taiwan Normal University, Taipei City, Taiwan

Dr. Keith V. Wolfe, Antioch, California, USA

Dr. Siddharth Kulkarni, The Hormiga Lab, The George Washington University, Washington,

D.C., USA

Dr. Tomas Ditrich, Faculty of Education, University of South Bohemia in Ceske

Budejovice, Czech Republic

Dr. Mihaly Foldvari, Natural History Museum, University of Oslo, Norway

Dr. V.P. Uniyal, Wildlife Institute of India, Dehradun, Uttarakhand 248001, India

Dr. John T.D. Caleb, Zoological Survey of India, Kolkata, West Bengal, India

Dr. Priyadarsanan Dharma Rajan, Ashoka Trust for Research in Ecology and the Environment

(ATREE), Royal Enclave, Bangalore, Karnataka, India

\section{Fishes}

Dr. Neelesh Dahanukar, IISER, Pune, Maharashtra, India

Dr. Topiltzin Contreras MacBeath, Universidad Autónoma del estado de Morelos, México

Dr. Heok Hee Ng, National University of Singapore, Science Drive, Singapore

Dr. Rajeev Raghavan, St. Albert's College, Kochi, Kerala, India

Dr. Robert D. Sluka, Chiltern Gateway Project, A Rocha UK, Southall, Middlesex, UK

Dr. E. Vivekanandan, Central Marine Fisheries Research Institute, Chennai, India

Dr. Davor Zanella, University of Zagreb, Zagreb, Croatia

Dr. A. Biju Kumar, University of Kerala, Thiruvananthapuram, Kerala, India

Dr. Akhilesh K.V., ICAR-Central Marine Fisheries Research Institute, Mumbai Research

Centre, Mumbai, Maharashtra, India

Dr. J.A. Johnson, Wildlife Institute of India, Dehradun, Uttarakhand, India

Amphibians

Dr. Sushil K. Dutta, Indian Institute of Science, Bengaluru, Karnataka, India

Dr. Annemarie Ohler, Muséum national d'Histoire naturelle, Paris, France

\section{Reptiles}

Dr. Gernot Vogel, Heidelberg, Germany

Dr. Raju Vyas, Vadodara, Gujarat, India

Dr. Pritpal S. Soorae, Environment Agency, Abu Dubai, UAE.

Prof. Dr. Wayne J. Fuller, Near East University, Mersin, Turkey

Prof. Chandrashekher U. Rivonker, Goa University, Taleigao Plateau, Goa. India

Dr. S.R. Ganesh, Chennai Snake Park, Chennai, Tamil Nadu, India

Dr. Himansu Sekhar Das, Terrestrial \& Marine Biodiversity, Abu Dhabi, UAE
Birds

Dr. Hem Sagar Baral, Charles Sturt University, NSW Australia

Dr. Chris Bowden, Royal Society for the Protection of Birds, Sandy, UK

Dr. Priya Davidar, Pondicherry University, Kalapet, Puducherry, India

Dr. J.W. Duckworth, IUCN SSC, Bath, UK

Dr. Rajah Jayapal, SACON, Coimbatore, Tamil Nadu, India

Dr. Rajiv S. Kalsi, M.L.N. College, Yamuna Nagar, Haryana, India

Dr. V. Santharam, Rishi Valley Education Centre, Chittoor Dt., Andhra Pradesh, India

Dr. S. Balachandran, Bombay Natural History Society, Mumbai, India

Mr. J. Praveen, Bengaluru, India

Dr. C. Srinivasulu, Osmania University, Hyderabad, India

Dr. K.S. Gopi Sundar, International Crane Foundation, Baraboo, USA

Dr. Gombobaatar Sundev, Professor of Ornithology, Ulaanbaatar, Mongolia

Prof. Reuven Yosef, International Birding \& Research Centre, Eilat, Israel

Dr. Taej Mundkur, Wetlands International, Wageningen, The Netherlands

Dr. Carol Inskipp, Bishop Auckland Co., Durham, UK

Dr. Tim Inskipp, Bishop Auckland Co, Durham, UK

Dr. V. Gokula, National College, Tiruchirappalli, Tamil Nadu, India

Dr. Arkady Lelej, Russian Academy of Sciences, Vladivostok, Russia

Dr. Simon Dowell, Science Director, Chester Zoo, UK

Dr. Mário Gabriel Santiago dos Santos, Universidade de Trás-os-Montes e Alto Douro,

Quinta de Prados, Vila Real, Portugal

Dr. Grant Connette, Smithsonian Institution, Royal, VA, USA

Dr. M. Zafar-ul Islam, Prince Saud Al Faisal Wildlife Research Center, Taif, Saudi Arabia

Mammals

Dr. Giovanni Amori, CNR - Institute of Ecosystem Studies, Rome, Italy

Dr. Anwaruddin Chowdhury, Guwahati, India

Dr. David Mallon, Zoological Society of London, UK

Dr. Shomita Mukherjee, SACON, Coimbatore, Tamil Nadu, India

Dr. Angie Appel, Wild Cat Network, Germany

Dr. P.O. Nameer, Kerala Agricultural University, Thrissur, Kerala, India

Dr. Ian Redmond, UNEP Convention on Migratory Species, Lansdown, UK

Dr. Heidi S. Riddle, Riddle's Elephant and Wildlife Sanctuary, Arkansas, USA

Dr. Karin Schwartz, George Mason University, Fairfax, Virginia.

Dr. Lala A.K. Singh, Bhubaneswar, Orissa, India

Dr. Mewa Singh, Mysore University, Mysore, India

Dr. Paul Racey, University of Exeter, Devon, UK

Dr. Honnavalli N. Kumara, SACON, Anaikatty P.O., Coimbatore, Tamil Nadu, India

Dr. Nishith Dharaiya, HNG University, Patan, Gujarat, India

Dr. Spartaco Gippoliti, Socio Onorario Società Italiana per la Storia della Fauna "Giuseppe

Altobello", Rome, Italy

Dr. Justus Joshua, Green Future Foundation, Tiruchirapalli, Tamil Nadu, India

Dr. H. Raghuram, The American College, Madurai, Tamil Nadu, India

Dr. Paul Bates, Harison Institute, Kent, UK

Dr. Jim Sanderson, Small Wild Cat Conservation Foundation, Hartford, USA

Dr. Dan Challender, University of Kent, Canterbury, UK

Dr. David Mallon, Manchester Metropolitan University, Derbyshire, UK

Dr. Brian L. Cypher, California State University-Stanislaus, Bakersfield, CA

Dr. S.S. Talmale, Zoological Survey of India, Pune, Maharashtra, India

Prof. Karan Bahadur Shah, Budhanilakantha Municipality, Kathmandu, Nepal

Dr. Susan Cheyne, Borneo Nature Foundation International, Palangkaraja, Indonesia

Dr. Hemanta Kafley, Wildlife Sciences, Tarleton State University, Texas, USA

\section{Other Disciplines}

Dr. Aniruddha Belsare, Columbia MO 65203, USA (Veterinary)

Dr. Mandar S. Paingankar, University of Pune, Pune, Maharashtra, India (Molecular)

Dr. Jack Tordoff, Critical Ecosystem Partnership Fund, Arlington, USA (Communities)

Dr. Ulrike Streicher, University of Oregon, Eugene, USA (Veterinary)

Dr. Hari Balasubramanian, EcoAdvisors, Nova Scotia, Canada (Communities)

Dr. Rayanna Hellem Santos Bezerra, Universidade Federal de Sergipe, São Cristóvão, Brazil

Dr. Jamie R. Wood, Landcare Research, Canterbury, New Zealand

Dr. Wendy Collinson-Jonker, Endangered Wildlife Trust, Gauteng, South Africa

Dr. Rajeshkumar G. Jani, Anand Agricultural University, Anand, Gujarat, India

Dr. O.N. Tiwari, Senior Scientist, ICAR-Indian Agricultural Research Institute (IARI), New

Delhi, India

Dr. L.D. Singla, Guru Angad Dev Veterinary and Animal Sciences University, Ludhiana, India

Dr. Rupika S. Rajakaruna, University of Peradeniya, Peradeniya, Sri Lanka

Dr. Bahar Baviskar, Wild-CER, Nagpur, Maharashtra 440013, India

Reviewers 2018-2020

Due to pausity of space, the list of reviewers for $2018-2020$ is available online.

The opinions expressed by the authors do not reflect the views of the Journal of Threatened Taxa, Wildlife Information Liaison Development Society, Zoo Outreach Organization, or any of the partners. The journal, the publisher, the host, and the partners are not responsible for the accuracy of the political boundaries shown in the maps by the authors.

Journal of Threatened Taxa is indexed/abstracted in Bibliography of Systematic Mycology, Biological Abstracts, BIOSIS Previews, CAB Abstracts, EBSCO, Google Scholar, Index Copernicus, Index Fungorum, JournalSeek, National Academy of Agricultural Sciences, NewJour, OCLC WorldCat, SCOPUS, Stanford University Libraries, Virtual Library of Biology, Zoological Records.

NAAS rating (India) 5.64
Print copies of the Journal are available at cost. Write to:

The Managing Editor, JoTT,

c/o Wildlife Information Liaison Development Society,

No. 12, Thiruvannamalai Nagar, Saravanampatti - Kalapatti Road,

Saravanampatti, Coimbatore, Tamil Nadu 641035, India

ravi@threatenedtaxa.org 


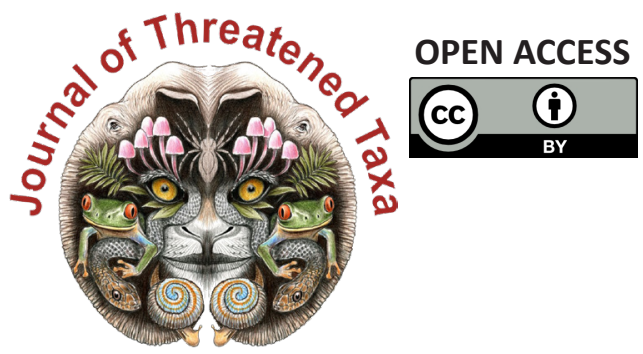

www.threatenedtaxa.org

The Journal of Threatened Taxa (JoTT) is dedicated to building evidence for conservation globally by publishing peer-reviewed articles online every month at a reasonably rapid rate at www.threatenedtaxa.org. All articles published in JoTT are registered under Creative Commons Attribution 4.0 International License unless otherwise mentioned. JoTT allows allows unrestricted use, reproduction, and distribution of articles in any medium by providing adequate credit to the author(s) and the source of publication.

\section{ISSN $0974-7907$ (Online) | ISSN $0974-7893$ (Print)}

\section{December 2021 | Vol. 13 | No. 14 | Pages: 20143-20310 \\ Date of Publication: 26 December 2021 (Online \& Print) DOI: 10.11609/jott.2021.13.14.20143-20310}

\section{Communications}

Updated distribution of seven Trichosanthes L. (Cucurbitales: Cucurbitaceae) taxa in India, along with taxonomic notes

Kanakasabapathi Pradheep, Soyimchiten, Ganjalagatta Dasaiah Harish, Muhammed Abdul Nizar, Kailash Chandra Bhatt, Anjula Pandey \& Sudhir Pal Ahlawat, Pp. 20143-20152

Dragonflies and Damselflies (Insecta: Odonata) of Aryanad Grama Panchayat, Kerala, India

- Reji Chandran \& A. Vivek Chandran, Pp. 20153-20166

Checklist of Odonata (Insecta) of Doon Valley, Uttarakhand, India

- Kritish De, Sarika Bhatt, Amar Paul Singh, Manisha Uniyal \& Virendra Prasad Uniyal, Pp. 20167-20173

Diversity of moths from the urban set-up of Valmiki Nagar, Chennai, India - Vikas Madhav Nagarajan, Rohith Srinivasan \& Mahathi Narayanaswamy, Pp. 20174-20189

Ichthyofaunal diversity with relation to environmental variables in the snowfed Tamor River of eastern Nepal

- Jawan Tumbahangfe, Jash Hang Limbu, Archana Prasad, Bhrarat Raj Subba \& Dil Kumar Limbu, Pp. 20190-20200

Observations on the foraging behavior of Tricoloured Munia Lonchura malacca (Linnaeus, 1766) and its interaction with pearl millet fields in Villupuram District, Tamil Nadu, India

- M. Pandian, Pp. 20201-20208

Roosting patterns of House Sparrow Passer domesticus Linn., 1758 (Aves: Passeridae) in Bhavnagar, Gujarat, India

- Foram P. Patel \& Pravinsang P. Dodia, Pp. 20209-20217

Review

Comprehensive checklist of algal class Chlorophyceae (sensu Fritsch, 1935) for Uttar Pradesh, India, with updated taxonomic status

- Sushma Verma, Kiran Toppo \& Sanjeeva Nayaka, Pp. 20218-20248

\section{View Point}

Wildlife managers ignore previous knowledge at great risk: the case of Rivaldo, the iconic wild Asian Elephant Elephas maximus L. of the Sigur Region, Nilgiri Biosphere Reserve, India

- Jean-Philippe Puyravaud \& Priya Davidar, Pp. 20249-20252

\section{Short Communications}

Diversity and distribution of macro lichens from Kalpetta Municipality of Wayanad District, Kerala, India

- Greeshma Balu, A.R. Rasmi, Stephen Sequeira \& Biju Haridas, Pp. 20253-20257

Extended distribution of two endemic epiphytes from the Western Ghats to the Deccan Plateau

- Sonali Vishnu Deore, Mangala Dala Sonawane \& Sharad Suresh Kambale, Pp. 20258-20260

Nomenclatural notes and report of Boehmeria penduliflora Wedd. ex D.G. Long from the Terai region of Uttar Pradesh, India

- Amit Gupta, Imtiyaz Ahmad Hurrah, Aparna Shukla \& Vijay V. Wagh, Pp. 2026120265
New distribution record of a true coral species, Psammocora contigua (Esper, 1794) from Gulf of Kachchh Marine National Park \& Sanctuary, India - R. Chandran, R. Senthil Kumaran, D.T. Vasavada, N.N. Joshi \& Osman G. Husen, Pp. 20266-20271

A new species of flat-headed mayfly Afronurus meenmutti (Ephemeroptera: Heptageniidae: Ecdyonurinae) from Kerala, India

- Marimuthu Muthukatturaja \& Chellaiah Balasubramanian, Pp. 20272-20277

Photographic record of Dholes predating on a young Banteng in southwestern Java, Indonesia

- Dede Aulia Rahman, Mochamad Syamsudin, Asep Yayus Firdaus, Herry Trisna Afriandi \& Anggodo, Pp. 20278-20283

Latrine site and its use pattern by Large Indian Civet Viverra zibetha Linnaeus, 1758: record from camera trap

- Bhuwan Singh Bist, Prashant Ghimire, Basant Sharma, Chiranjeevi Khanal \& Anoj Subedi, Pp. 20284-20287

Notes

Two additions to the flora of Kerala, India

- P. Murugan, Basil Paul \& M. Sulaiman, Pp. 20288-20291

Pentatropis R.Br. ex Wight \& Arn. (Apocynaceae), a new generic record for Kerala, India

- V. Ambika, Jose Sojan \& V. Suresh, Pp. 20292-20294

New record of Kashmir Birch Mouse Sicista concolor leathemi (Thomas, 1893) (Rodentia: Sminthidae) in the Indian Himalaya

- S.S. Talmale, Avtar Kaur Sidhu \& Uttam Saikia, Pp. 20295-20298

Breeding record of Black-headed Ibis Threskiornis melanocephalus (Aves: Threskiornithidae) at Mavoor wetland, Kozhikode District, Kerala, India - C.T. Shifa, Pp. 20299-20301

\section{Response}

Crop and property damage caused by Purple-faced Langurs Trachypithecus vetulus (Mammalia: Primates: Cercopithecidae) - Vincent Nijman, Pp. 20302-20306

Reply

If habitat heterogeneity is effective for conservation of butterflies in urban landscapes of Delhi, India? Unethical publication based on data manipulation: Response of original authors

- Monalisa Paul \& Aisha Sultana, Pp. 20307-20308

\section{Book Review}

Freshwater fishes of the Arabian Peninsula - Rajeev Raghavan, Pp. 20309-20310

Publisher \& Host

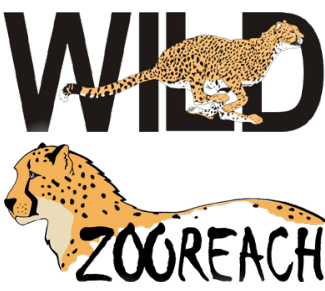

Threatened Taxa 